\title{
Long-term survival after lung resection for non-small cell lung cancer with circulatory bypass: A systematic review
}

\author{
Ashok Muralidaran, MD, ${ }^{\text {a }}$ Frank C. Detterbeck, MD, ${ }^{a}$ Daniel J. Boffa, MD, ${ }^{\mathrm{a}}$ Zuoheng Wang, PhD, ${ }^{\mathrm{b}}$ and \\ Anthony W. Kim, MD
}

Objective: Resection of locally advanced non-small cell lung cancer using circulatory bypass is not frequently performed. The objective of this study was to systematically review the long-term survival associated with the published studies dealing with the performance of lung resections for non-small cell lung cancer using circulatory bypass.

\begin{abstract}
Methods: A systematic review of publications dealing with lung resections for non-small cell lung cancer under circulatory bypass spanning from January 1, 1990, to December, 31 2010, was performed using a PubMed search with specific inclusion and exclusion criteria. The primary end point collected was survival. Several other clinical variables were also collected and analyzed. Survival curves were calculated using the Kaplan-Meier method. Univariate comparisons of survival were performed using a Cox proportional hazard model. Multivariate analysis was carried out using a Cox regression model.
\end{abstract}

Results: The search algorithm yielded 20 articles for the analysis. The overall 5 -year survival was $37 \%$ (median, $36 \pm 6$ months). Survival was significantly higher when placement on bypass was planned (54\%; median, $67 \pm$ 19 months) as opposed to unplanned or emergency placement ( $11 \%$; median, $19 \pm 6$ months; $P=.006)$. Multivariate analysis demonstrated that the use of unplanned bypass was prognostic for a worse long-term survival (hazard ratio $=0.28 ; 95 \%$ confidence interval, $0.09-0.90 ; P=.033$ ). The 30-day and 90 -day perioperative mortalities were $0 \%$ and $1 \%$, respectively.

Conclusions: The literature over the past 2 decades demonstrates that favorable long-term survival for extended resections of locally advanced non-small cell lung cancer using circulatory bypass can be achieved. The use of unplanned cardiopulmonary bypass, though, seems to be prognostic of unfavorable long-term survival. (J Thorac Cardiovasc Surg 2011;142:1137-42)

Despite technical advances in extracorporeal circulatory support, lung resections for advanced thoracic malignancies under circulatory bypass $(\mathrm{CPB})$ are relatively uncommon. The underuse of CPB may reflect the reluctance among surgeons to embrace an aggressive approach because of concerns of an inevitable poor prognosis or fears of CPB-induced tumor dissemination. The objective of this review was to systematically review the long-term survival associated with published lung resections for non-small cell lung cancer (NSCLC) performed using CPB.

\section{MATERIALS AND METHODS \\ Search Strategy \\ A systematic search was performed using the PubMed database to iden- tify published articles reporting pulmonary resections using CPB. Original}

\footnotetext{
From the Section of Thoracic Surgery, School of Medicine, ${ }^{a}$ Department of Epidemiology and Public Health, ${ }^{\text {b }}$ Yale University, New Haven, Conn.

Disclosures: Authors have nothing to disclose with regard to commercial support.

Received for publication March 14, 2011; revisions received June 26, 2011; accepted

for publication July 20, 2011; available ahead of print Aug 24, 2011.

Address for reprints: Anthony W. Kim, MD, Yale University School of Medicine,

Section of Thoracic Surgery, 330 Cedar St, BB 205, New Haven, CT 06520

(E-mail: anthony.kim@yale.edu).

$0022-5223 / \$ 36.00$

Copyright (c) 2011 by The American Association for Thoracic Surgery

doi:10.1016/j.jtcvs.2011.07.042
}

articles, case series, and individual reports from January 1, 1990, to December 31, 2010, were considered. Inclusion criteria were publications that described resections requiring $\mathrm{CPB}$ support for an intent-to-cure resection. Publications were excluded if the central focus of the study involved (1) combined cardiac-pulmonary procedures, that is, resections performed under CPB primarily for a cardiac procedure with a concomitant pulmonary resection; and (2) lesions involving the carina necessitating a carinal resection. Exceptions to these included publications in which a minority of the indications for CPB included carinal resections in a larger series.

A Boolean search strategy using the search term "non-small cell lung cancer" identified 32,970 articles, and "cardiopulmonary bypass" identified 27,491 articles (Figure 1). A combined search revealed 18 publications. "Lung cancer" identified 191,888 articles and "circulatory bypass" scored 12,099 hits. A combined search identified 32 articles. A combination of "cardiopulmonary bypass" and "lung cancer" had the highest yield of 209 articles. After reviewing the titles and, when appropriate, the abstract or actual articles, 17 articles were selected for further review, and the rest were rejected for meeting the exclusion criteria. Four additional articles were identified from the references of these studies and included for full review. These articles were then reviewed thoroughly for completeness of information and to exclude any duplicity in publication, as was the case in 1 article. Ultimately, $20 \operatorname{articles}^{1-20}$ were used for the analysis (Figure 1, Table 1).

\section{Variables Recorded and Evaluated}

The primary end point collected was survival. Several clinical data were also collected, including age, gender, organ resected, histology, pathologic $\mathrm{T}$ status, pathologic $\mathrm{N}$ status, tumor stage, bypass type, planned bypass, use of induction therapy, surgical approach, resection type, use of adjuvant 


\section{Abbreviations and Acronyms \\ $\mathrm{CPB}=$ circulatory bypass \\ NSCLC $=$ non-small cell lung cancer}

therapy, and start and end of the study period. The organ involvement prompting the resection under CPB included the aorta, left atrium/pulmonary veins, pulmonary arteries, and right atrium/inferior and superior vena cava complex.

When collected and analyzed, the clinical variables were assigned categoric values for the purposes of comparison. For data that were numeric, the variables were dichotomized on the basis of their mean values.

Although an extended effort was made to abstract the variables from each of the publications reviewed, all of the variables were not universally provided in each article. Because of the presence of unavailable data during the abstraction process, an arbitrary cutoff of $70 \%$ was selected to establish a minimum amount of information that was thought to be reasonable to enter into the analysis. The $70 \%$ cutoff was chosen because it was thought that this figure would allow for the authors to report generalizable results. Of note, this cutoff seemed to be a natural break in the data that were provided (Table 2). Ultimately, CPB time, achievement of an R0 resection, and adjuvant chemotherapy or radiation therapy were excluded from the analysis.

\section{Statistical Analysis}

Survival curves based on the clinical data collected were calculated using the Kaplan-Meier method. Univariate comparison of survivals between the grouped variables within specific clinical data was performed using a Cox proportional hazard model. Multivariate analysis was carried out using a Cox regression model. The study characteristics that were analyzed were selected from those variables in the univariate analysis that achieved a $P$ value of less than .1. We used bootstrapping, a resampling technique, to verify the model used in the multivariate analysis. We generated 1000 bootstrap samples while retaining the censoring percentage as in the observed dataset. The significance of the 3 variables was reassessed on the basis of the estimates obtained from the bootstrap. Statistical analysis was performed using the statistical package R, version 2.10.1.

No formal analysis of study quality or publication bias was performed. There was no formal funding source for this study. The authors had complete control of the search, data analysis, and writing. No other individuals were involved.

\section{RESULTS}

\section{Patient Characteristics}

There were 72 patients identified with a mean age of $55 \pm$ 10 years. In 65 patients, the majority of examined variables were obtained. There were 15 female patients $(21 \%)$ among the 71 patients for whom gender was reported.

A summary of the clinical data recorded is listed in Table 3. Stage information was provided for 70 patients. The majority of patients $(84 \%)$ had stage IIIB, and the aorta was the most commonly resected organ $(43 \%)$. One third of the patients had squamous carcinoma. There were 31 of 58 patients $(53 \%)$ who received some form of induction therapy. Pneumonectomy was the most commonly performed resection $(74 \%)$. There were 27 of 49 patients $(55 \%)$ who had any adjuvant therapy.

\section{Univariate Analysis}

Univariate analysis was possible for 71 patients (Table 4). For this entire cohort, the 5-year survival was $37 \%$ (median survival, $36 \pm 6$ months) (Figure 2). A planned CPB was associated with a significantly higher survival than an unplanned/emergency placement of the patient on bypass $(P=.006)$ (Figure 3). Aortic resection had a better survival, albeit nonsignificantly, compared with other mediastinal organs $(P=.065)$. Publications after 2004 reported a nonsignificantly higher survival than earlier publications $(P=.062)$. The remainder of the clinical variables-the type of CPB (routine vs femoro-femoral vs passive aorta to aorta shunt), histology (nonsquamous vs squamous), induction therapy vs none, and type of incision (thoracotomy vs sternotomy) - did not demonstrate significantly different survivals.

\section{Multivariate Analysis}

A multivariate analysis $(\mathrm{n}=52)$ was performed analyzing 3 variables: organ resected (aorta vs other), CPB (planned vs unplanned), and publication year (before 2004 vs after 2004). Multivariate analysis revealed that survival was significantly lower for an unplanned/emergency placement of the patient on bypass compared with a planned $\mathrm{CPB}(P=.033)$ (Table 5), although the significance was lost after bootstrap evaluation $(P=.072)$ (Table 6).

\section{Perioperative Mortality}

The incidences of 30-day and 90-day perioperative mortality were $0 \%$ and $1 \%$, respectively.

\section{DISCUSSION}

Lung cancers involving vital mediastinal vascular structures are often considered high risk for resection and thought to be associated with a poor prognosis. Martini and colleagues ${ }^{21}$ observed a $19 \% 5$-year survival for patients with T3 and T4 lesions with mediastinal involvement when excluding those patients with $\mathrm{N} 2$ disease, whereas a more recent study observed a $34.8 \%$ 5-year survival for patients with T4 lesions managed surgically. ${ }^{22}$ Few reports exist in the western literature detailing their resection using circulatory support, and our analysis of these studies raises some interesting results.

\section{Favorable Survival With Circulatory Bypass, Particularly in a Planned Setting}

Despite $84 \%$ of the patients having stage IIIB disease and $82 \%$ of lesions being classified as $\mathrm{T} 4$, the overall 5 -year survival was a remarkable $37 \%$ (median survival, $36 \pm 6$ months). Survival was significantly higher when resections were performed under CPB in a planned, nonemergency setting.

In contrast, the reported 5-year survival for stage IIIB NSCLC is $3 \%$ to $7 \%$ with a median survival of 13.7 months 


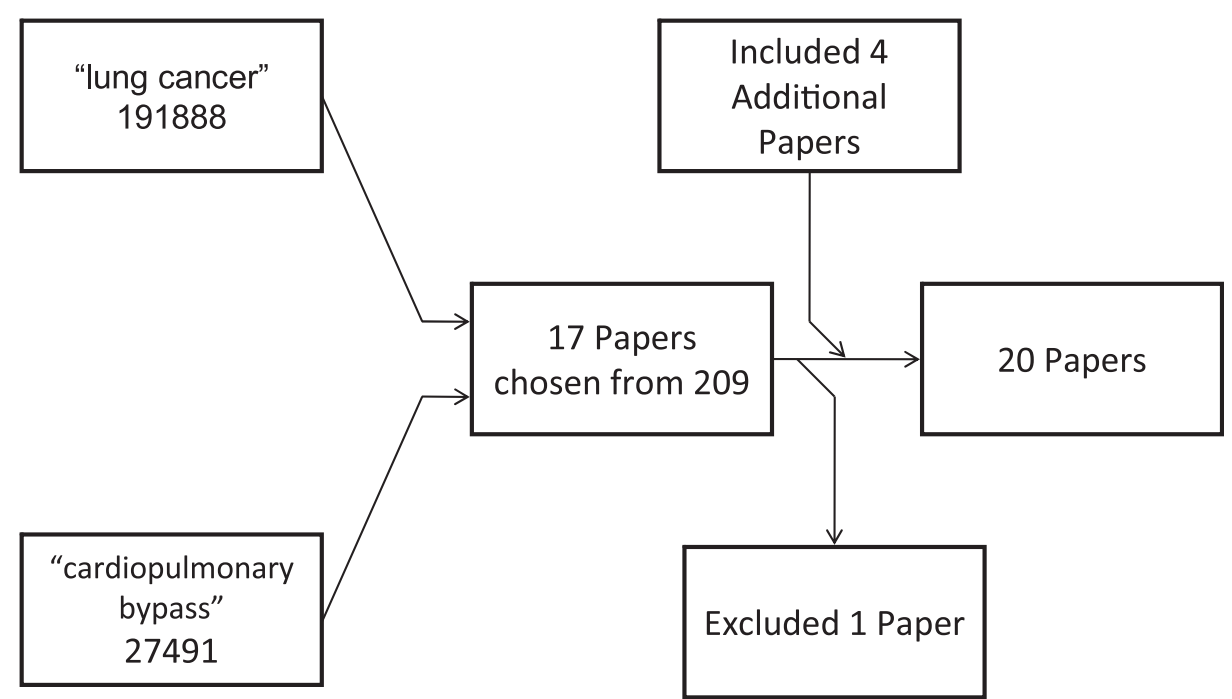

FIGURE 1. Search algorithm.

after chemotherapy and radiation and 9.6 months after radiation therapy alone. ${ }^{23} \mathrm{~A}$ phase II trial exploring surgery after chemoradiation for stage IIIA (N2) and IIIB disease observed an overall 3-year survival of $24 \% .{ }^{24}$ Only $40 \%$ of patients had stage IIIB disease, and this group had a median survival of 19 months.

\section{Histology Not Significant in Resection Using Circulatory Bypass}

Most of the NSCLCs invading mediastinal structures are by definition central, with few exceptions. Squamous cell

TABLE 1. Studies used in the systematic review analysis

\begin{tabular}{|c|c|c|}
\hline First author & Year of publication & $\begin{array}{l}\text { No. of patients obtained } \\
\text { from study }\end{array}$ \\
\hline Kodama $^{1}$ & 1990 & 2 \\
\hline Shirakusa $^{2}$ & 1991 & 4 \\
\hline Horita $^{3}$ & 1993 & 2 \\
\hline $\operatorname{Ricci}^{4}$ & 1994 & 2 \\
\hline Okubo $^{5}$ & 1996 & 1 \\
\hline Ernst $^{6}$ & 1999 & 1 \\
\hline Sugio $^{7}$ & 1999 & 1 \\
\hline Klepetko $^{8}$ & 1999 & 4 \\
\hline Ferguson ${ }^{9}$ & 2000 & 1 \\
\hline Vaporciyan $^{10}$ & 2002 & 1 \\
\hline Hasegawa $^{11}$ & 2003 & 11 \\
\hline Baron $^{12}$ & 2003 & 4 \\
\hline Byrne $^{13}$ & 2004 & 7 \\
\hline de Perrot $^{14}$ & 2005 & 7 \\
\hline $\mathrm{Ohta}^{15}$ & 2005 & 13 \\
\hline Wiebe ${ }^{16}$ & 2006 & 3 \\
\hline Nomori $^{17}$ & 2005 & 1 \\
\hline Shiraishi $^{18}$ & 2005 & 5 \\
\hline Vojacek $^{19}$ & 2006 & 1 \\
\hline Shimizu $^{20}$ & 2010 & 1 \\
\hline
\end{tabular}

cancers are more commonly central lesions compared with non-squamous lesions. In our analysis, squamous carcinomas did not prove more lethal compared with nonsquamous lesions. This finding was contrary to some ${ }^{21}$ and similar to other studies of surgical resection in locally advanced cancers where the histology was not a significant prognostic factor. ${ }^{22,25}$

\section{Organ Resected Less Important Than Other Factors}

Aside from histology, other factors were important in predicting improved survival using $\mathrm{CPB}$. The organ resected was not one of these factors, as Yildizeli and

TABLE 2. Availability of data for total number of patients included $(\mathbf{n}=\mathbf{7 2})$

\begin{tabular}{lc}
\hline \multicolumn{1}{c}{ Clinical variable } & \% For whom data available (n) \\
\hline Organ resected & $100(72)$ \\
CPB type & $100(72)$ \\
Year of publication & $100(72)$ \\
Pathologic T status & $99(71)$ \\
Surgical approach & $99(71)$ \\
Tumor stage & $97(70)$ \\
Histology & $94(68)$ \\
Age & $93(67)$ \\
Pathologic N status & $90(65)$ \\
Gender & $88(63)$ \\
Use of induction therapy & $82(59)$ \\
Resection type & $74(53)$ \\
Use of planned CPB & $74(53)$ \\
Use of adjuvant radiation therapy & $60(43)$ \\
Use of adjuvant chemotherapy & $56(40)$ \\
Performance of an R0 resection & $47(34)$ \\
CPB time & $40(29)$ \\
Values given in italics represent those variables for which $<70 \%$ of the data were \\
available and, therefore, not analyzed.
\end{tabular}


TABLE 3. Clinical variables

\begin{tabular}{|c|c|}
\hline \multicolumn{2}{|l|}{ Stage $(\mathrm{n}=70)$} \\
\hline IB & $1(1.4 \%$ \\
\hline IIA & $3(4.2 \%$ \\
\hline IIB & $4(6 \%)$ \\
\hline IIIA & $1(1.4 \%$ \\
\hline IIIB & $59(84 \%)$ \\
\hline IV & $2(3 \%)$ \\
\hline \multicolumn{2}{|l|}{ Organ resection $(\mathrm{n}=72)$} \\
\hline Aorta & $31(43 \%)$ \\
\hline Left atrium/pulmonary veins & $18(25 \%)$ \\
\hline Pulmonary artery & $8(11 \%)$ \\
\hline SVC/IVC/right atrial complex & $2(3 \%)$ \\
\hline Trachea & $2(3 \%)$ \\
\hline Other organs & $3(4 \%)$ \\
\hline$>1$ organ & $8(11 \%)$ \\
\hline \multicolumn{2}{|l|}{ Histology $(\mathrm{n}=72)$} \\
\hline Squamous & $32(37 \%)$ \\
\hline Nonsquamous & $40(63 \%)$ \\
\hline Adenocarcinoma & 27 \\
\hline Large cell carcinoma & 11 \\
\hline Other & 2 \\
\hline Induction therapy $(\mathrm{n}=58)$ & $31(53 \%)$ \\
\hline Chemotherapy & 12 \\
\hline Radiation therapy & 5 \\
\hline Chemoradiation therapy & 14 \\
\hline \multicolumn{2}{|l|}{ Resections $(\mathrm{n}=53)$} \\
\hline Pneumonectomy & $39(74 \%)$ \\
\hline Lobectomy & $13(24 \%)$ \\
\hline Bilobectomy & $1(2 \%)$ \\
\hline Adjuvant therapy $(\mathrm{n}=49)$ & $27(55 \%)$ \\
\hline Chemotherapy & 15 \\
\hline Radiation therapy & 10 \\
\hline Chemoradiation therapy & 2 \\
\hline
\end{tabular}

$S V C$, Superior vena cava; $I V C$, inferior vena cava.

colleagues $^{22}$ also observed. This finding was contrary to the studies by Fukuse and colleagues ${ }^{26}$ who found a lower survival with left atrial invasion compared with great vessel involvement, and Pitz and colleagues, ${ }^{25}$ who also observed better survival with great vessel involvement compared with other mediastinal structures. However, individual studies of organ resection show similar survivals. Studies of left atrial resections have reported 5-year survivals in the range of $14 \%$ to $16 \%,{ }^{27,28}$ with an earlier study having obtained a $22 \% 4$-year survival, but that included $\mathrm{T} 3$ lesions and stage IIIA disease. ${ }^{29}$ Venuta and colleagues ${ }^{30}$ observed a similar 19\% 5-year survival among their cohort of resected patients with stage IIIB and pulmonary artery involvement. A large study of superior vena cava resection showed a 21\% 5-year survival. ${ }^{31}$ The exception was the study by Misthos and colleagues. ${ }^{32}$ Their small population of patients with aortic resections showed a high 5-year survival of $30.7 \%$, but Misthos and colleagues included patients in whom only the parietal pleura overlying the aorta was involved. Such lesions involving only the adventitia
TABLE 4. Univariate analysis

\begin{tabular}{|c|c|c|c|c|}
\hline & $\mathbf{N}$ & $\begin{array}{c}\% 5-y \\
\text { survival }\end{array}$ & Median survival & $\boldsymbol{P}$ \\
\hline $\begin{array}{l}\text { Organ resected (aorta vs } \\
\text { other) }\end{array}$ & 71 & 49 vs 19 & $58 \pm 17$ vs $25 \pm 5$ & .065 \\
\hline Age $(>56$ vs $\leq 56$ y) & 66 & 33 vs 30 & $37 \pm 9$ vs $34 \pm 8$ & .940 \\
\hline Gender (M vs F) & 62 & 33 vs 26 & $38 \pm 8$ vs $31 \pm 12$ & .927 \\
\hline $\begin{array}{l}\text { Histology (squamous vs } \\
\text { non-squamous) }\end{array}$ & 67 & 23 vs 39 & $28 \pm 7$ vs $45 \pm 11$ & .140 \\
\hline pT status (4 vs other) & 70 & 25 vs 48 & $30 \pm 6$ vs $57 \pm 22$ & .653 \\
\hline $\mathrm{pN}$ status (N0 vs N1 + N2) & 64 & 44 vs 17 & $50 \pm 13$ vs $23 \pm 5$ & .209 \\
\hline Stage $(\leq$ IIIA vs $\geq$ IIIB $)$ & 69 & 52 vs 24 & $64 \pm 29$ vs $29 \pm 5$ & .650 \\
\hline Bypass type (CPB vs other) & 71 & 23 vs 47 & $29 \pm 6$ vs $55 \pm 17$ & .355 \\
\hline $\begin{array}{l}\text { Induction therapy (no vs } \\
\text { other) }\end{array}$ & 59 & 34 vs 32 & $39 \pm 10$ vs $36 \pm 9$ & .820 \\
\hline $\begin{array}{l}\text { Surgical approach } \\
\text { (thoracotomy vs other) }\end{array}$ & 70 & 26 vs 42 & $30 \pm 6$ vs $49 \pm 15$ & .346 \\
\hline $\begin{array}{l}\text { Resection (lobe vs } \\
\text { pneumonectomy) }\end{array}$ & 52 & 29 vs 17 & $34 \pm 15$ vs $24 \pm 5$ & .244 \\
\hline Planned CPB (yes vs no) & 52 & 54 vs 11 & $67 \pm 19$ vs $19 \pm 6$ & .006 \\
\hline $\begin{array}{l}\text { Study start ( } \geq 2004 \text { vs } \\
<2004)\end{array}$ & 71 & 47 vs 14 & $55 \pm 14$ vs $21 \pm 5$ & .062 \\
\hline
\end{tabular}

of the thoracic aorta could be classified as T3 and not T4, per Grunenwald. ${ }^{33}$ The overall picture emerging from these studies in which resections were performed without CPB seems to be congruent with our observation that there is no significant survival difference based on the specific organ resected.

\section{Lymph Node Status Not Important in Predicting Survival in Circulatory Bypass Cohort}

A substantial amount of clinical research has been devoted to the impact of lymph node status with respect to

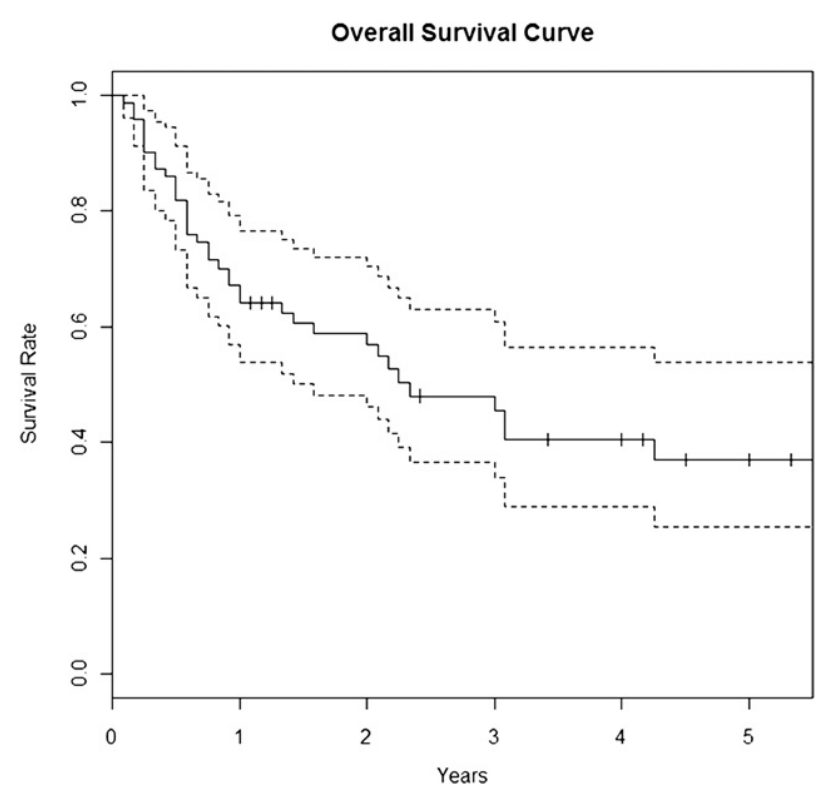

FIGURE 2. Overall survival. 


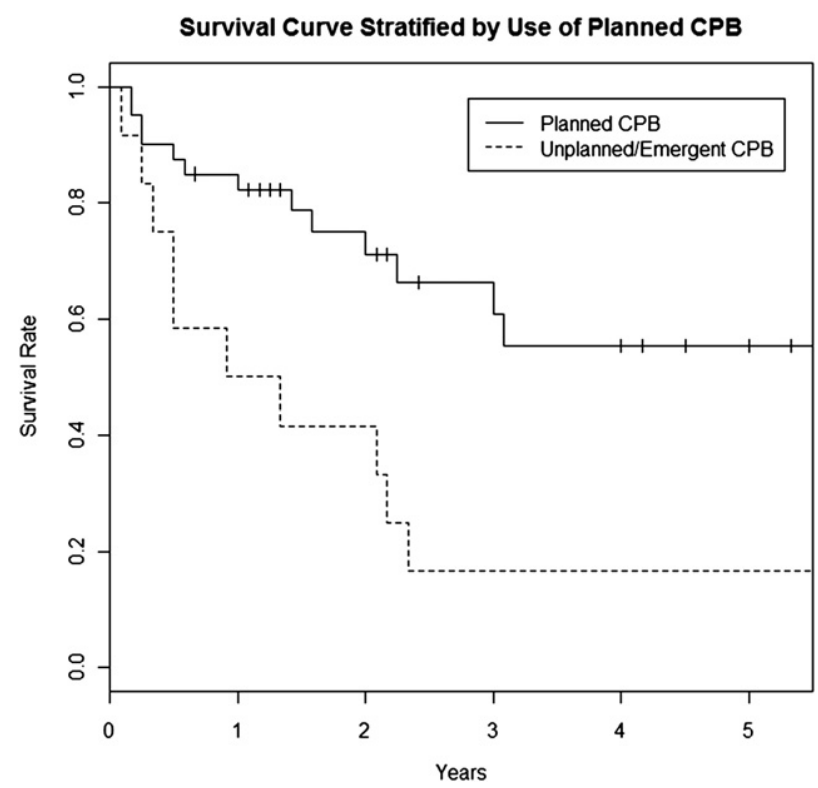

FIGURE 3. Survival stratified by use of planned versus unplanned bypass. $C P B$, Circulatory bypass.

survival in locoregionally advanced disease. In general, a more advanced lymph node status has been found to be predictive of worse long-term survival ${ }^{34}$ as is the number sampled $^{35}$ and found positive. ${ }^{36}$ The findings of this systematic review are contrary to these findings in that the nodal status (N0 vs N1-2) was not predictive of a better or worse survival. This is in contrast with other studies ${ }^{7,9}$ and the study by Doddoli and colleagues, ${ }^{37}$ who observed a difference in median survival of 16 versus 9 months comparing N0-1 with N2 disease in NSCLC invading mediastinal structures. Bernard and colleagues ${ }^{38}$ also observed a significantly lower survival among T4 cancers invading mediastinal structures when both the superior and inferior mediastinal nodes were involved. The lack of an adequate sample size may have affected the power of our study, explaining the above findings. The other limitation is that there may be a reporting bias in the studies we gleaned from the literature.

\section{Study Limitations}

Although publication bias was not formally evaluated, there must be a strong bias to present the successful resections rather than those that ended suboptimally. This is evidenced by the outstanding survival in a population of

TABLE 5. Multivariate analysis

\begin{tabular}{lccc}
\hline & No. & Hazard ratio [95\% CI] & $\boldsymbol{P}$ \\
\hline $\begin{array}{l}\text { Organ resected (aorta vs } \\
\quad \text { other) }\end{array}$ & 26 vs 26 & $1.11[0.34-3.67]$ & .863 \\
Planned bypass (yes vs no) & 40 vs 12 & $0.28[0.09-0.90]$ & .033 \\
Study start $(\geq 2004$ vs $<2004)$ & 38 vs 14 & $0.58[0.23-1.45]$ & .243 \\
\hline
\end{tabular}

CI, Confidence interval.
TABLE 6. Multivariate analysis with bootstrap

\begin{tabular}{lccc}
\hline & No. & Hazard ratio [95\% CI] & $\boldsymbol{P}$ \\
\hline $\begin{array}{l}\text { Organ resected (aorta vs } \\
\quad \text { other) }\end{array}$ & 26 vs 26 & $1.11[0.31-4.59]$ & .879 \\
Planned bypass (yes vs no) & 40 vs 12 & $0.28[0.06-0.97]$ & .072 \\
Study start $(\geq 2004$ vs $<2004)$ & 38 vs 14 & $0.58[0.21-1.50]$ & .306 \\
\hline CI, Confidence interval. & & &
\end{tabular}

CI, Confidence interval.

patients statistically known to have poor survival. Perhaps more than survival, the extremely low perioperative mortality rate suggests that the group of patients presented in the literature may represent a skewed population. The message, however, is that successful complete resections can be performed in carefully selected scenarios using CPB support.

Another limitation of this study is associated with the use of limited data for analysis given the incompleteness of the data provided in the articles reviewed. Also, most of the case reports/series had 5 or fewer patients. Nevertheless, an attempt was made to only evaluate those clinical variables for which $70 \%$ of the data from the aggregate group of patients were provided. Although the study was perhaps not as statistically stringent as is normally performed, we think it was a reasonable attempt to achieve a certain level of robustness to the data.

Last, this study included patients who underwent less than full $\mathrm{CPB}$, thereby introducing some heterogeneity into the patients analyzed. Nevertheless, this may have been justified because this does not diminish the fact that a substantial operation was performed that required some form of adjunct circulatory support, which is not physiologically experienced during routine resections. Furthermore, this fact also does not diminish the theoretically detrimental effect of circulating tumor cells via extracorporeal support, a modality that intuitively would be to contribute to worse long-term outcomes secondary to fostering metastasis, ${ }^{39}$ although such an occurrence has been contested. ${ }^{40,41}$ Along similar lines, a minority of patients had less than stage III disease; therefore, there was heterogeneity in expected survival, perhaps weighting it toward a more favorable outcome. It certainly could be argued that adding those patients who underwent simultaneous cardiac and pulmonary operations for cardiac disease and malignancy may have served as a comparison group for both of these latter 2 issues, but this was outside the scope of this review.

\section{CONCLUSIONS}

Our study points to a favorable outcome for locally advanced NSCLC when an extended resection is undertaken under CPB in well-chosen candidates. A planned use of a true CPB seemed to provide the best benefit. These favorable outcomes, however, must be interpreted with some caution because they are based on a unique subset of patients with NSCLC. 


\section{References}

1. Kodama K, Doi O, Tatsuta M. Unusual extension of lung cancer into the left atrium via the pulmonary vein. Int Surg. 1990;75:22-6.

2. Shirakusa T, Kimura M. Partial atrial resection in advanced lung carcinoma with and without cardiopulmonary bypass. Thorax. 1991;46:484-7.

3. Horita K, Itho T, Ueno T. Radical operation using cardiopulmonary bypass for lung cancer invading the aortic wall. Thorac Cardiovasc Surg. 1993;41: 130-2.

4. Ricci C, Rendina EA, Venuta F, Ciriaco PP, De Giacomo T, Fadda GF. Reconstruction of the pulmonary artery in patients with lung cancer. Ann Thorac Surg. 1994;57:627-33.

5. Okubo K, Yagi K, Yokomise H, Inui K, Wada H, Hitomi S. Extensive resection with selective cerebral perfusion for a lung cancer invading the aortic arch. Eur J Cardiothorac Surg. 1996;10:389-91.

6. Ernst M, Koller M, Grobholz R, Moosdorf R. Both atrial resection and superior vena cava replacement in sleeve pneumonectomy for advanced lung cancer. Eur J Cardiothorac Surg. 1999;15:530-2.

7. Sugio K, Sakada T, Saito G, Maruyama R, Nishioka K, Tominaga R, et al. Extended resection of the pulmonary artery and the aorta for primary lung cancer. Report of a case. J Cardiovasc Surg (Torino). 1999;40:749-51.

8. Klepetko W, Wisser W, Birsan T, Mares P, Taghavi S, Kupilik N, et al. T4 lung tumors with infiltration of the thoracic aorta: is an operation reasonable? Ann Thorac Surg. 1999;67:340-4.

9. Ferguson ER Jr, Reardon MJ. Atrial resection in advanced lung carcinoma under total cardiopulmonary bypass. Tex Heart Inst J. 2000;27:110-2.

10. Vaporciyan AA, Rice D, Correa AM, Walsh G, Putnam JB, Swisher S, et al. Resection of advanced thoracic malignancies requiring cardiopulmonary bypass. Eur J Cardiothorac Surg. 2002;22:47-52.

11. Hasegawa S, Bando T, Isowa N, Otake Y, Yanagihara K, Tanaka F, et al. The use of cardiopulmonary bypass during extended resection of non-small cell lung cancer. Interact Cardiovasc Thorac Surg. 2003;2:676-9.

12. Baron O, Jouan J, Sagan C, Despins P, Michaud JL, Duveau D. Resection of bronchopulmonary cancers invading the left atrium-benefit of cardiopulmonary bypass. Thorac Cardiovasc Surg. 2003;51:159-61.

13. Byrne JG, Leacche M, Agnihotri AK, Paul S, Bueno R, Mathisen DJ, et al. The use of cardiopulmonary bypass during resection of locally advanced thoracic malignancies: a 10-year two-center experience. Chest. 2004;125:1581-6.

14. de Perrot M, Fadel E, Mussot S, de Palma A, Chapelier A, Dartevelle P. Resection of locally advanced (T4) non-small cell lung cancer with cardiopulmonary bypass. Ann Thorac Surg. 2005;79:1691-7.

15. Ohta M, Hirabayasi H, Shiono H, Minami M, Maeda H, Takano H, et al. Surgical resection for lung cancer with infiltration of the thoracic aorta. J Thorac Cardiovasc Surg. 2005;129:804-8.

16. Wiebe K, Baraki H, Macchiarini P, Haverich A. Extended pulmonary resections of advanced thoracic malignancies with support of cardiopulmonary bypass. Eur J Cardiothorac Surg. 2006;29:571-8.

17. Nomori H, Hirotani T, Watanabe K, Ohtsuka T, Naruke T, Suemasu K. Extended resection of lung cancer invading the left subclavian artery by using cardiopulmonary bypass. Ann Thorac Cardiovasc Surg. 2005;11:211-3.

18. Shiraishi T, Shirakusa T, Miyoshi T, Yamamoto S, Hiratsuka M, Iwasaki A, et al Extended resection of T4 lung cancer with invasion of the aorta: is it justified? Thorac Cardiovasc Surg. 2005;53:375-9.

19. Vojacek J, Burkert J, Pafko P, Mates M, Spatenka J, Pavel P. Extension of pulmonary adenocarcinoma into the left atrium. Asian Cardiovasc Thorac Ann. 2006; 14:e99-101.

20. Shimizu J, Ikeda C, Arano Y, Adachi I, Morishita M, Yamaguchi S, et al. Advanced lung cancer invading the left atrium, treated with pneumonectomy combined with left atrium resection under cardiopulmonary bypass. Ann Thorac Cardiovasc Surg. 2010;16:286-90.
21. Martini N, Yellin A, Ginsberg RJ, Bains MS, Burt ME, McCormack PM, et al. Management of non-small cell lung cancer with direct mediastinal involvement. Ann Thorac Surg. 1994;58:1447-51.

22. Yildizeli B, Dartevelle PG, Fadel E, Mussot S, Chapelier A. Results of primary surgery with T4 non-small cell lung cancer during a 25 -year period in a single center: the benefit is worth the risk. Ann Thorac Surg. 2008;86:1065-75.

23. Jett JR, Scott WJ, Rivera MP, Sause WT. Guidelines on treatment of stage IIIB non-small cell lung cancer. Chest. 2003;123:221S-5.

24. Albain KS, Rusch VW, Crowley JJ, Rice TW, Turrisi AT 3rd, Weick JK, et al. Concurrent cisplatin/etoposide plus chest radiotherapy followed by surgery for stages IIIA (N2) and IIIB non-small-cell lung cancer: mature results of Southwest Oncology Group phase II study 8805. J Clin Oncol. 1995;13:1880-92.

25. Pitz CC, Brutel de la Riviere A, van Swieten HA, Westermann CJ, Lammers JW, van den Bosch JM. Results of surgical treatment of T4 non-small cell lung cancer. Eur J Cardiothorac Surg. 2003;24:1013-8.

26. Fukuse T, Wada H, Hitomi S. Extended operation for non-small cell lung cancer invading great vessels and left atrium. Eur J Cardiothorac Surg. 1997;11:664-9.

27. Ratto GB, Costa R, Vassallo G, Alloisio A, Maineri P, Bruzzi P. Twelve-year experience with left atrial resection in the treatment of non-small cell lung cancer. Ann Thorac Surg. 2004;78:234-7.

28. Kuehnl A, Lindner M, Hornung HM, Winter H, Jauch KW, Hatz RA, et al. Atrial resection for lung cancer: morbidity, mortality, and long-term follow-up. World $J$ Surg. 2010;34:2233-9.

29. Tsuchiya R, Asamura H, Kondo H, Goya T, Naruke T. Extended resection of the left atrium, great vessels, or both for lung cancer. Ann Thorac Surg. 1994;57: 960-5.

30. Venuta F, Ciccone AM, Anile M, Ibrahim M, De Giacomo T, Coloni GF, et al. Reconstruction of the pulmonary artery for lung cancer: long-term results. $J$ Thorac Cardiovasc Surg. 2009;138:1185-91.

31. Spaggiari L, Magdeleinat P, Kondo H, Thomas P, Leon ME, Rollet G, et al. Results of superior vena cava resection for lung cancer. Analysis of prognostic factors. Lung Cancer. 2004;44:339-46.

32. Misthos P, Papagiannakis G, Kokotsakis J, Lazopoulos G, Skouteli E, Lioulias A. Surgical management of lung cancer invading the aorta or the superior vena cava. Lung Cancer. 2007;56:223-7.

33. Grunenwald DH. Surgery for advanced stage lung cancer. Semin Surg Oncol. 2000;18:137-42.

34. Mountain CF, Dresler CM. Regional lymph node classification for lung cancer staging. Chest. 1997;111:1718-23.

35. Ludwig MS, Goodman M, Miller DL, Johnstone PA. Postoperative survival and the number of lymph nodes sampled during resection of node-negative non-small cell lung cancer. Chest. 2005; 128:1545-50.

36. Lee JG, Lee CY, Park IK, Kim DJ, Park SY, Kim KD, et al. Number of metastatic lymph nodes in resected non-small cell lung cancer predicts patient survival. Ann Thorac Surg. 2008;85:211-5.

37. Doddoli C, Rollet G, Thomas P, Ghez O, Seree Y, Giudicelli R, et al. Is lung cancer surgery justified in patients with direct mediastinal invasion? Eur J Cardiothorac Surg. 2001;20:339-43.

38. Bernard A, Bouchot O, Hagry O, Favre JP. Risk analysis and long-term survival in patients undergoing resection of T4 lung cancer. Eur J Cardiothorac Surg. 2001;20:344-9.

39. Hasegawa S, Otake Y, Bando T, Cho H, Inui K, Wada H. Pulmonary dissemination of tumor cells after extended resection of thyroid carcinoma with cardiopulmonary bypass. J Thorac Cardiovasc Surg. 2002;124:635-6.

40. Akchurin RS, Davidov MI, Partigulov SA, Brand JB, Shiriaev AA, Lepilin MG, et al. Cardiopulmonary bypass and cell-saver technique in combined oncologic and cardiovascular surgery. Artif Organs. 1997;21:763-5.

41. Gillinov AM, Greene PS, Stuart RS, Heitmiller RF. Cardiopulmonary bypass as an adjunct to pulmonary surgery. Chest. 1996;110:571-4. 